\title{
Value chain financing and plantain production in Nigeria: an ex-ante approach
}

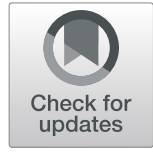

\author{
Mathew Paul Ojo ${ }^{1 *}$ and Adeolu Babatunde Ayanwale ${ }^{2}$
}

\author{
* Correspondence: mathewojo@ \\ ymail.com \\ ${ }^{1}$ Justice Development and Peace \\ Movement (JDPM), Rural \\ Development Programme, Oyo \\ town, Nigeria \\ Full list of author information is \\ available at the end of the article
}

\begin{abstract}
Value chain finance (VCF) represents the aligning and structuring of finance within a value chain or as a result of its existence. Given the growing need to explore innovative approaches to rural and agricultural finance in Nigeria, such financing solutions have become imperative. However, few studies on the ex-ante impact of financing innovations exist. Therefore, to ascertain the benefits derivable from VCF, this paper analyzes the potential impact of VCF on plantain production in Nigeria. The expected benefits are estimated based on the economic surplus model, using the Dynamic Research Evaluation for Management (DREAM) software. Results from a 25 -year simulation period at a 15\% discount rate and an innovation cost of USD $1,300,000$, show that, in the least optimistic scenario, the economy is expected to have an overall net gain (economic surplus) of USD 3256,800, with a net present value of USD 3406,880, benefit-cost ratio of 3.83, and an internal rate of return or break-even discount rate of $36.80 \%$. These results indicate the positive impact of VCF, measured in terms of net present value and net benefit, expressed as producer and consumer surplus. This suggests VCF is a viable and beneficial financing innovation for food production in Nigeria. Finally, it is recommended that a value chain financing agency be established to make finance available to farmers to boost food production in Nigeria.
\end{abstract}

Keywords: Ex-ante, Plantain, Value chain, Finance, Innovation, Production

\section{Introduction}

Smallholder farmers face several challenges in increasing productivity. However, access to requisite financing has been noted to be a critical challenge in many developing countries (Anang, Sipiläinen, Bäckman and Kola, 2015). Therefore, bridging the financing gap of these farmers must become a priority. Where this is absent, farmers often rely on informal instruments, which although are accessible and flexible they are also inefficient and costly in the short term and do not always offer the support needed to help transform subsistence farming into a profitable business (Okonjo-Iweala and Madan, 2016). Unfortunately, due to the challenges associated with delivering rural and agricultural finance, most commercial financial institutions are not interested in financing farmers and other rural clients because they represent a less familiar, riskier, and less profitable market than their more traditional urban clientele (World Council of Credit Union (WOCCU, 2009). There is thus the need to urgently explore innovative approaches to rural and agricultural finance (IFPRI, 2010).

(c) The Author(s). 2019 Open Access This article is distributed under the terms of the Creative Commons Attribution 4.0 International License (http://creativecommons.org/licenses/by/4.0/), which permits unrestricted use, distribution, and reproduction in any medium, provided you give appropriate credit to the original author(s) and the source, provide a link to the Creative Commons license, and indicate if changes were made. 
In this context, value chain financing (VCF) presents an innovative approach to rural and agricultural financing, as it enables the understanding of both financing within a value chain and financing tailored to fit a value chain (Miller and Jones, 2010). Specifically, agricultural VCF is the financing of agriculture and agribusiness within a chain, aligning and structuring finance with the chain or as a result of its existence (AfDB, 2013). Fundamentally, this framework hinges on market orientation, without which the resulting financial services would fail, and its approach requires that financial institutions consider the financial potential of the entire value chain, not only the creditworthiness of individuals. This focus shift allows financial institutions to more accurately measure and mitigate risk. However, this type of finance is not always available, and actors in agricultural and rural value chains frequently complain about the lack of access to financial services (WOCCU, 2009).

In Nigeria, the various financing windows provided by the federal government through the Central Bank of Nigeria (CBN) are presently not fully utilized by farmers due to a lack of awareness. Further, many of the previously implemented financing initiatives were rather from an "intervention perspective" than a participatory perspective, often ignoring the need for farmers' participation in drawing out financing initiatives. Therefore, while these financing measures have attempted to overcome existing barriers and expand access to formal finance in rural communities, their success has been rather elusive. As a result, many rural households in Nigeria still lack access to reliable and affordable finance for agriculture and other livelihood activities (IFPRI, 2010). In this context, the VCF approach ensures that actors within a value chain are actively involved in the process and creation of financial products that fit the chain, as well as agree with the financing institutions on the workable and acceptable modalities for such financing.

The plantain (Musa Spp) is considered a "high value crop" with enormous potential, Nigeria being ranked among the 20 most important plantain-producing countries worldwide (Food and Agriculture Organization, 2011). However, the production concentrated in the southern part of the country is inconsistent and low, being mostly produced by small-scale farmers (Federal Office of Statistics, 1999; Akinyemi, Aiyelaagbe and Akyeampong, 2010). Therefore, an increased plantain production through VCF is desirable, as the crop has the ability to contribute to food security, employment, diversification of income sources in rural and urban areas, and gross national product Nkenda and Akyeampong (2003).

While there exist ex-ante studies in agriculture using the economic surplus model, many of these studies however focused on innovations as it concerns inputs such as crop varieties, fertilizers and herbicides. Ex-ante studies on innovative agricultural financing initiatives are very rare. Also, many studies have analyzed ex-post the impact of financing initiatives, studies on the ex-ante impact of financing innovations (i.e., prior to their implementation) are scarce. This literature gap has partly contributed to the lack of success of some previous financing initiatives in Nigeria such as the Agricultural Credit Guarantee Scheme Fund (ACGSF) initiated since 1978; Small and Medium Enterprises Equity Investment Scheme (SMEEIS); Refinancing and Rediscounting Facility (RRF), established in 2002 and; The Large Scale Agricultural Credit Scheme (LASACS), established in 2009. The more recently initiated financing programmes includes the Anchor Borrowers Programme (ABP) initiated by the Central Bank of 
Nigeria in 2016 as well as the Nigeria Incentive-Based Risk-Sharing System for Agricultural Lending (NIRSAL). Many of these financing initiatives were implemented with little or no appreciable impact on agricultural production as no initial studies were carried out to determine their potential impact before implementation.

This study however focuses on assessing the potential benefits derivable from VCF in meeting the financial needs of plantain producers towards increasing production.

\section{Literature review}

\section{Economic surplus and measurement of social gains}

The economic surplus approach allows for the estimation of economic benefits generated by the adoption of technological innovations, compared to the situation before (without) adoption, when only traditional technology was available (Wander et al., 2004). Figure 1 shows the impact of technology innovation on economic surplus. If the supply curve moves to the right due to positive impacts of innovation on productivity and cost reduction, the consumer achieves gain of $\mathrm{B}+\mathrm{C}$ (i.e., the consumer is benefiting from research because the price is decreasing). The producer loses area $\mathrm{B}$ due to price reduction but gains area A due to the increasing demand. The impact on the producer depends on the elasticity of demand and supply curves. Therefore, the benefit of innovation for the society will be the sum of areas A and C. However, as shown by Masters et al. (1996), sensitivity analysis ensured that the elasticities of supply and demand have little influence in determining economic surplus compared to other variables (e.g., price, productivity, quantity). Therefore, the economic surplus method requires information on productivity increases generated by innovation, equilibrium price of assessed product, adoption rate and costs, timeframe between innovation and

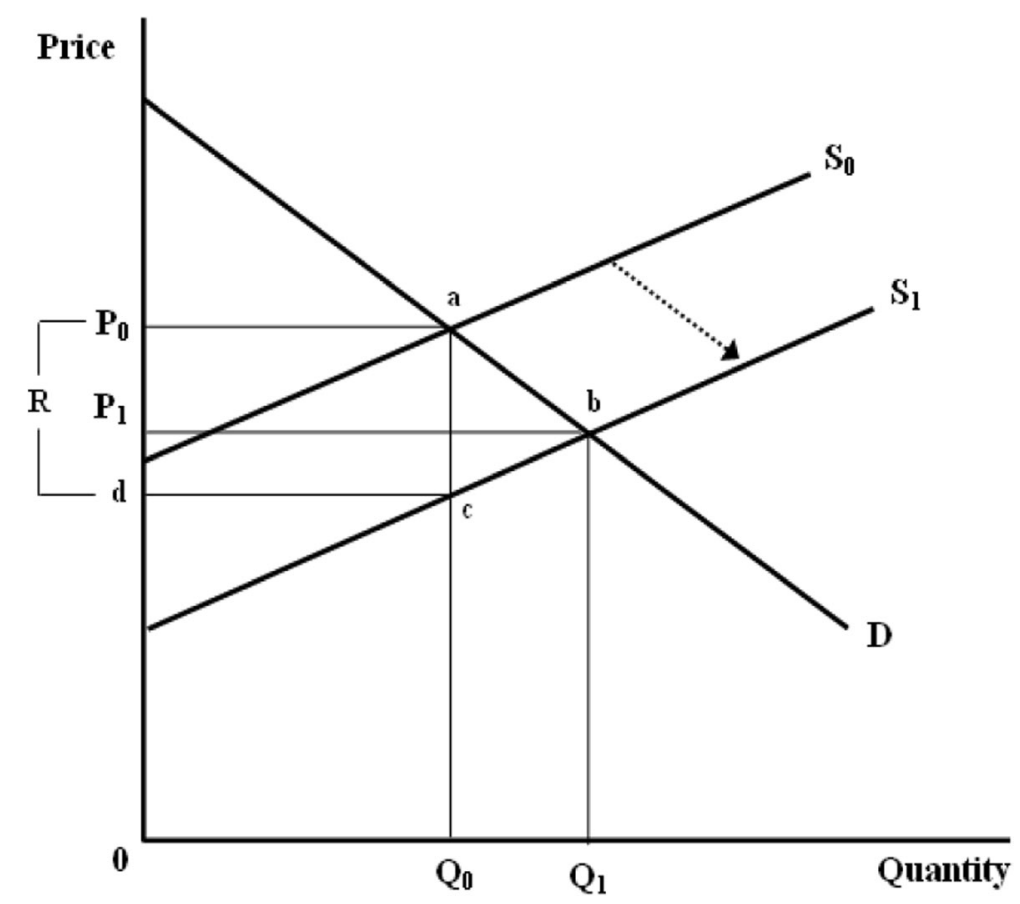

Fig. 1 Impact of innovation on economic surplus. Source: Adapted from Norton et al. (2005) 
adoption, and price elasticity of supply and demand. With this information available, it is possible to calculate the magnitude of the change in the supply curve as a result of the adoption of technological innovations (Maredia et al., 2000).

\section{Economic surplus and innovation in agricultural production}

The concept of economic surplus is the most widely used method to analyze the economic impact generated by agricultural research (Avila and Ayres, 1987). Avila (2001) noted that, under this approach, the coefficients on price elasticities of the demand and supply curves of the product under evaluation, shift of the supply curve, price changes, and production values of the product area are used. As the supply curve would be located on the left-hand side if no technological innovation is generated by agricultural research, he concluded that, when innovation occurs, consumers benefit from the increase in the supply of products and the producers from the reduction of production costs.

Impact assessment aims to determine the consequences of an intervention on development. The analysis can either be ex-ante (i.e., conducted prior to the intervention) or ex-post (i.e., after the project is implemented). The former analysis can help with difficult decision making for the allocation of limited resources and is based on some type of prediction model, while the latter can determine the impact of past investments in innovation on target beneficiaries, as it is measured at some point in time after the intervention has taken place (Macharia et al., 2012). As resources for agricultural innovation and development have become increasingly scarce worldwide (Anderson et al., 1994), ex-ante impact assessments of the potential benefits and research costs or innovation investments are being used by more national and international research centers to aid in priority setting and resource allocation (Anderson, 1992). The economic surplus model has been thus used to measure the benefits of crop research in inducing supply changes (e.g., Norton et al., 1987). According to Harberger (1971) and Rudi (2008), three assumptions must hold for an economic surplus analysis: the competitive demand price for a given unit measures the value of that unit to the demander; the competitive supply price for a given unit measures the value of that unit to the supplier; and when evaluating the net benefits or costs of a given action (project, program, or policy), the costs and benefits accruing to each member of the relevant group (i.e. family, city, state, nation, world) should be added without regard to the individuals to whom they accrue.

\section{Empirical studies on the economic surplus model}

Several empirical studies apply economic surplus in evaluating the impacts of new agricultural technologies. These studies treat specific new technology evaluations in diverse market contexts. For instance, Norton et al. (1987) estimated the potential benefits of an agricultural research and extension program in Peru. Their study examined the effects of demand shifts over time and the influence of government pricing policies on research benefits. Pimental et al. (1992) estimated environmental and social costs of pesticides in the United States, concluding that applying pesticides costing USD 4 billion resulted in USD 16 billion savings for a given year, while environmental and social costs amounted to USD 8 billion. Mills (1998) evaluated the potential impact of public sector research on maize with and without trade barriers on foreign trade in Kenya. 
They used an ex-ante technique, emphasizing the importance of relaxing the trade barriers for the benefit of consumers.

Hareau et al. (2006) used ex-ante evaluation of the economic impact of herbicide-resistant transgenic rice in Uruguay. They found that the benefit for a multinational company that would develop the technology was USD 0.55 million. Moyo et al. (2007) proposed a procedure for predicting the ex-ante impacts of agricultural research on aggregate poverty and applied it to estimate the poverty-reducing impact of peanut research in Uganda. Rusike et al. (2010) carried out an ex-ante evaluation of cassava development research in Malawi, their results showing a high proportion of farm households are not self-sufficient in food production and can be assisted by increasing land and labor productivity in production for the processing and marketing of cassava to reduce deficits and increase market surplus. Ayanwale et al. (2011) assessed the potential economic benefits derivable from the adoption of the Integrated Agricultural Research for Development (IAR4D) approach in the Sudan Savanna taskforce using the Kano-Katsina-Maradi Pilot Learning Site. Their results showed that IAR4D research and the extension concept yielded an estimated rate of return higher than the prevailing market interest rate and confirmed that adopting the approach generated several benefits in excess of research and extension expenditures. Macharia et al. (2012) assessed the potential economic and poverty impacts of 11 improved chickpea varieties released by the Ethiopian Institute of Agricultural Research. Using an economic surplus model, they estimated a total benefit of USD 111 million over 30 years. Consumers were estimated to obtain 39\% of the benefit, and producers, $61 \%$. The benefit-cost ratio (BCR) was estimated at 5:1 and the internal rate of return at $55 \%$, indicating the investment is profitable. They believe that the generated benefit was expected to lift more than 0.7 million people (both producers and consumers) out of poverty, and concluded that further investments in chickpea and other legume research in Ethiopia is justified for poverty alleviation.

These studies, among others, used the economic surplus model to measure the economic impact of research or innovation vis-a-vis their investment costs. However, their focus was more on production inputs, such as seeds, fertilizers, chemicals, and improved varieties. While these inputs are necessary and important for any agricultural production, innovations are not limited to agricultural production inputs. According to Ellinger and Barry (2015), in the current risky economic environment, credit should be managed as closely and as carefully as other production inputs as, similar to seeds and chemicals, agricultural credit is changing and expanding with new and innovative products. This study thus considers the scare and limited nature of financial resources in the form of credit, using the economic surplus model to measure the potential impact of VCF as a form of financial innovation for agricultural production to ascertain the benefits or detriments of such innovation prior to implementation. As such, this study makes a methodological contribution to the application of the economic surplus model.

\section{Materials and methods}

\section{Data collection and analysis}

Primary data (e.g., quantity of plantain produced, price, yield) were collected through a multi-stage sampling procedure from 300 plantain farmers in three states of the southwest region of Nigeria. The region was selected because it is one of the major centers 
of plantain production in the country (Akinyemi et al., 2010). Secondary data were sourced from the National Bureau of statistics (NBS), CBN, journals, and other publications. The expected benefits of VCF on plantain production were analyzed using the economic surplus model through the Dynamic Research Evaluation for Management (DREAM) software developed for the International Food Policy Research Institute (IFPRI) by Wood, You, and Baitx (2001).

\section{Economic surplus model}

The introduction of VCF as a financing innovation is expected to result in an outward shift of the plantain supply curve. Following Wander, Magalhaes, Vedovoto, and Martins (2004) and Rudi (2008), this technology-induced change is treated as an intercept change (a shift in factor $\mathrm{k}$ ) in the supply plantain curve, along with the respective quantities supplied and demanded. Following Alston et al. (1995), the absolute relative reduction in price is measured by Z. Changes in producer, consumer, and total surplus are estimated by $\mathrm{K}$ and $\mathrm{Z}$ and are calculated as:

$$
\begin{aligned}
& K=\left\{\left[(\mu-\alpha)-P_{0}(\beta+\mu)\right] / \beta\right\} p_{s} \\
& Z=\left[\left(P_{1}-P_{0}\right) / P_{1}\right]=-\left[\frac{K \varepsilon_{s}}{(\varepsilon+\eta)]}\right.
\end{aligned}
$$

In each year, the downward shift from the initial market equillibrium price of the supply curve due to VCF-induced cost savings from the initial market equillibrium price before the supply shift is $\mathrm{P}_{0}$, while $\mathrm{P}_{1}$ represents the new equilibrium price due to increased plantain production; $\varepsilon_{\mathrm{s}}$ and $\eta$ are the supply and demand elasticities, respectively; $\mu$ is the intercept of the demand curve; $\alpha$ and $\beta$ are the slopes of the demand and supply curves, respectively; and $\mathrm{p}_{\mathrm{s}}$ is the probability of success of the innovation. Additionally, the changes in producer, consumer, and total surplus in a closed economy are given by eqs. (3-6). The notations are described in Table 1 . The summary of parameters used for the economic surplus analysis is shown in Table 2.

$$
\begin{aligned}
& \Delta \mathrm{TS}=\mathrm{P}_{0} \mathrm{Q}_{0} \mathrm{~K}(1+0.5 \mathrm{Z \eta}), \\
& \Delta \mathrm{CS}=\mathrm{P}_{0} \mathrm{Q}_{0} \mathrm{Z}(1+0.5 \mathrm{Z \eta}), \\
& \Delta \mathrm{PS}=\mathrm{P}_{0} \mathrm{Q}_{0}(\mathrm{~K}-\mathrm{Z})(1+0.5 \mathrm{Z \eta}), \\
& \mathrm{K}=(\mathrm{E}(\mathrm{Y}) / \varepsilon-\mathrm{E}(\mathrm{C}) / 1+\mathrm{E}(\mathrm{Y})) \mathrm{p} \mathrm{A}_{\mathrm{t}}(1-\mathrm{dt}) .
\end{aligned}
$$

The model also estimates the social gain indicators from investment in VCF innovation. By introducing into the model, the flows of investments in the deployment of VCF, indicators of social gains such as the net present value (NPV), internal rate of return (IRR), and the BCR were estimated. Knowing the benefits and costs of the innovation throughout a period of time, it is possible to carry out profitability analyses to show its economic viability. NPV in the year $t$ is equal to a flow of benefits generated by an investment minus a flow of costs of this investment discounted by an appropriate rate. If NPV is positive, then investment in the VCF innovation is considered profitable (Wander et al., 2004). 
Table 1 Notations and description

\begin{tabular}{ll}
\hline Variable & Description \\
\hline$P_{0}$ & Initial equilibrium price of plantain \\
$Q_{0}$ & Initial equilibrium quantity of plantain \\
$Z$ & Relative reduction in price due to supply shift \\
$\varepsilon$ & Supply elasticity \\
$\eta$ & Demand elasticity \\
$K$ & Shift of the plantain supply curve as a proportion of the initial price \\
$\Delta T S$ & Change in total surplus \\
$\Delta C S$ & Change in consumer surplus \\
$\Delta P S$ & Change in producer surplus \\
$E(Y)$ & Expected proportionate yield change ( $D$ per Ha) due to the adoption of VCF \\
$E(C)$ & Expected proportionate change in variable input costs ( $\Delta$ per Ha) from adoption \\
$P$ & Probability of success for achieving the expected yield change from adoption \\
$A_{t}$ & Adoption rate of VCF at time $t$ \\
$d_{t}$ & Rate of depreciation of the new technology/innovation \\
\hline
\end{tabular}

$$
N P V_{t}=P V(B)_{t}-P V(C)_{t}=\sum_{j=0} \frac{\left(B_{t+j}-C_{t+j}\right)}{(I+i)^{j}}
$$

IRR is the rate that turns the NPV to zero or turns the present value of benefits equals the present value of costs. The IRR should be higher than the rates available on the market for alternative capital use to consider the investment in the VCF innovation as profitable.

Table 2 Summary of parameters for economic surplus analysis

\begin{tabular}{|c|c|c|c|}
\hline Variables & Value & Description & Source \\
\hline Base year & 2016 & The start year for simulation & Baseline data \\
\hline Simulated period (years) & 25 & Number of projected years & Baseline data \\
\hline Discount rate (\%) & 15 & Derived from lending rate of ACGS & $\mathrm{CBN}$ \\
\hline Price $P_{o}$ (USD/ton) & 292 & Average price of plantain per ton & Baseline data \\
\hline Production $Q_{0}$ (tons/year) & 54,665 & Average quantity of plantain in tons & Baseline data \\
\hline Consumption (tons/year) & 54,665 & Average quantity of plantain consumed & Baseline data \\
\hline Demand elasticity $(\varepsilon)$ & 0.52 & Assumed for plantain & Author \\
\hline Supply elasticity ( $\eta$ ) & 1 & Plantain supply elasticity & Alston et al. (1995) \\
\hline Annual crop growth rate (\%) & 4 & Growth rate (2015-2016) & CBN (2016) \\
\hline Consumption growth rate $C_{0}(\%)$ & 2.8 & Population growth rate used as proxy & UN (2015) \\
\hline Yield at present (Ton) & 13,500 & Yield at start of simulation & Baseline data \\
\hline Percentage yield increase $(\Delta \mathrm{Y})$ & 18 & Percentage change in yield of plantain & Baseline data \\
\hline Innovation time lag (years) & 3 & Time frame for VCF implementation & WOCCU (2009) \\
\hline Adoption lag (years) & 5 & Time frame for adoption of VCF & Baseline data \\
\hline Maximum adoption level (\%) & 50 & Projected maximum adoption level & Ayanwale et al. (2011) \\
\hline Minimum adoption level (\%) & 10 & Estimated minimum adoption level & Akinola et al. (2009) \\
\hline Cost of VCF (USD) & $1.3 \mathrm{~m}$ & Estimated cost of deploying VCF & WOCCU (2009) \\
\hline
\end{tabular}

Source: Author's compilation 


$$
0=\sum_{j=0} \frac{\left(B_{i+j}-C_{i+j}\right)}{(I+I R R)^{j}}
$$

$\mathrm{BCR}$ represents the relationship between the present value of the benefits and that of the costs. The investment in VCF is considered profitable if the BCR is above 1.

$$
B C R_{t}=\frac{P V(B)_{t}}{P V(C)_{t}}
$$

\section{Conceptual framework}

The VCF considered in this paper follows the four-phased approach of WOCCU (2007):

Phase I: Identification and evaluation of potential value chains. Under this design, the financing outfit (credit unions, large processors, Banks, NGOs, Government establishment, etc.) first ensures that market demand exists for the commodity and that producers have the ability to meet demand because, without adequate product demand, both the financial institution and producers are at risk of significant loss. Second, an analysis of the strengths, weaknesses, opportunities, and threats of the value chain is carried out. Points along the value chain where providing access to finance could bring the greatest value and would represent a good investment for the financier are then identified. In other words, while every actor in a chain is considered before financing the chain, finance is not necessarily made available to every actor, but to the weakest link or actor where such financing would produce the greatest value to the entire chain. Finally, a scorecard tool is used to evaluate and rank the value chain and create a map of potential financing options.

Phase II: Facilitation and leveraging of market linkages. To help improve efficiency and reduce dependency on intermediaries, the financing outfit brings together all value chain participants to identify problems, review their needs based on the evaluation in phase I, and commit to finding solutions. This phase is thus characterized by obtaining production and financial data from the meetings held to design appropriate loan products, where the participants identify and contractually agree on quality standards, minimum purchase prices for produce, and non-financial activities that would improve value chain efficiency. These provide reliable market information to strengthen small producers' business relationships and secure market access. The commitment participants make in this phase becomes an integral part of mitigating the financial risk of lending.

Phase III: Designing of financial products and evaluation of capacity to pay. In this third phase, the financing outfit analyzes the potential cash flows based on the information gathered during the workshops organized during phase II. It then designs products that directly reflect the financing needs of borrowers and the specific characteristics of chain actors. The financing outfit conditions disbursement and repayment schedules on production cycles and sets competitive interest rates to cover costs and provide profit margins. It also establishes the policies and procedures needed to address the risks associated with value chain loans, especially those made directly to producers. It then determines the best combination of collateral and signed contracts to cover the loans. Phase III thus reduces the financial risk of granting loans with unrealistic terms and/or inadequate amounts. By premising loans on both participants' real needs and their capacity to pay, the financing outfit is more likely to increase productivity and guarantee repayment. 
Phase IV: Granting, monitoring, and collection of loan. The financing outfit disburses loans in cash or in vouchers, which permits borrowers to obtain discounted inputs such as quality plantain suckers, fertilizers, pesticides, tools, labor, and equipment from other value chain participants. In this stage, producer associations and technical assistance providers help monitor production, which reduces financial outfits' operational costs and allows them to reduce interest rates on loans. Once the buyers receive the products, they channel payments to producers or associations via the financial outfit. They, in turn, deduct the full loan payment of the principal plus interest from the sales amount and credit the balance to individuals' or producer associations' savings accounts. Financing can be made available to any value chain participant, such as input suppliers, producers, producer associations, processors, and buyers. However, this study considers the situation where the bulk of loans is intended for small producers and producer associations, who are often considered the most vulnerable, hence the focus on plantain producers.

The relationship between finance and growth, provides the basis on which value chain financing is considered to lead to growth in plantain production. In the growth model of Harrod and Domar (Hussain, 2000), the rate of capital accumulation plays a crucial role in determining growth. The model posits that the investment requirements for achieving a given growth rate are proportional to the growth rate by a constant known as the incremental capital output ratio. According to Department for International Development (2004), access to credit by individuals enables them to borrow funds and strengthen productive assets by investing in micro-enterprises; in productivity-enhancing new technologies such as new and better tools, equipment, or inputs such as fertilizers; or in education and health, thus facilitating greater capital accumulation and growth.

However, the sustainable provision of credit and rational use of other inputs in the right proportions and at the right time are believed to be crucial to increasing output and productivity. The process, procedure, and management of providing financing presents the grounds for innovation which, in turn, requires adoption by plantain producers. According to Ellis, Lemma, and Rud (2010), the potential contribution that access to financial services can make to growth and poverty reduction is now widely accepted in academic and policy circles.

The adoption of innovative financing approaches such as VCF is expected to provide financing in the form of credit available to producers, and this situation is expected to lead to increased plantain production. Here, the impact of adopting VCF is estimated ex-ante through the economic surplus model (Fig. 2). As previously discussed, following Alston, Norton, and Pardey (1995), several studies have applied the economic surplus model to estimate research and innovation benefits (Okike, 2002; Bantilan, Anupama and Joshi, 2005; Akinola, Alene, Adeyemo, Sanogo and Olanrewaju, 2009; Ayanwale, Akinola and Adeyemo, 2011).

\section{Results and discussion \\ Results}

\section{Discussion}

\section{Economic benefits of VCF for plantain production}

Table 3 presents the simulated cost and benefit of VCF for plantain production over a 25-year period in a closed economy. In a closed economy, there are no exports; therefore, all produced plantain is consumed locally. The first three years, representing the 


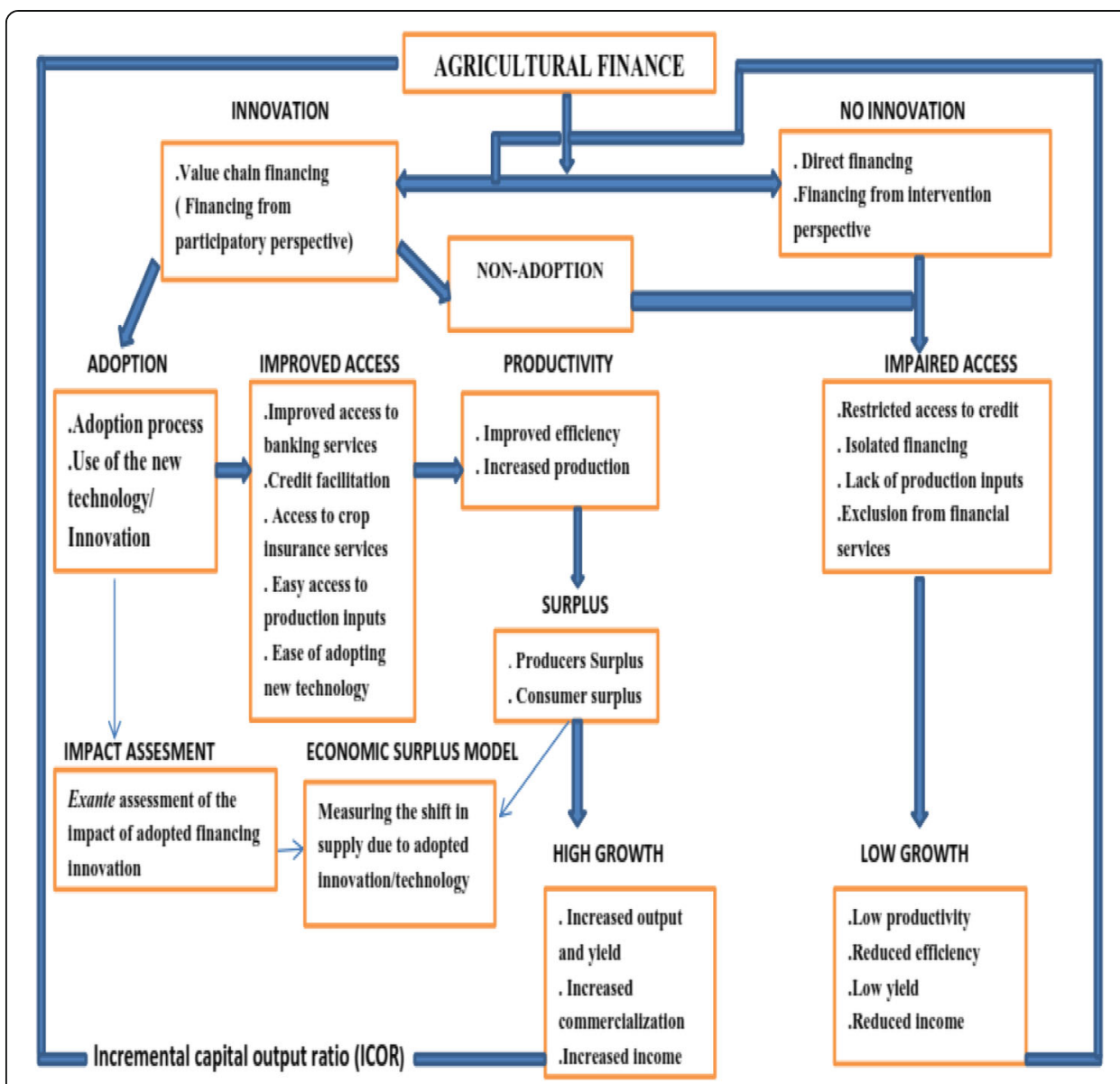

Fig. 2 Conceptual framework of VCF impact on plantain production. Source: The Author (2018)

innovation time lag, show that the total economic surplus of VCF innovation is negative over the period of implementing the innovation; thus, no economic surplus is recorded for the consumers or producers in this stage. However, in the fourth year, the producer surplus is USD 15,200 and consumer surplus USD 29,400, for a total economic surplus of USD 44,600, which increased to USD 260,400 in the fifth year. This represents the number of years that the adoption of the VCF innovation was expected to lag. This implies that investment in VCF would start yielding benefits only after the end of the third year. The benefits accruing from the adoption of VCF equal the amount that was invested in its implementation in the ninth year, with a total benefit of USD 1,309,200. At the end of the 25-year period, the total economic surplus of VCF innovation for plantain production was USD 2,173,900, with the producer benefit being USD 743,700 and the consumer benefit USD 1,430,200. The BCR of implementing the VCF innovation in the sixth column of the table shows that the total benefit derivable from VCF became higher than the cost of implementing VCF from the fourth year of implementation, for a total of 3256.8 at the end of the simulation period.

\section{Sensitivity analysis}

To determine the robustness of the simulated returns, parameters such as discount rate, adoption rate, yield change, and probability of success were varied to verify the 
Table 3 Simulated VCF Cost and Benefit on Plantain Production

\begin{tabular}{|c|c|c|c|c|c|}
\hline Year & $\begin{array}{l}\text { Producer } \\
\text { (USD '000) }\end{array}$ & $\begin{array}{l}\text { Consumer } \\
\text { (USD '000) } \\
\end{array}$ & $\begin{array}{l}\text { Total } \\
\text { (USD '000) }\end{array}$ & $\begin{array}{l}\text { Costs } \\
\text { (USD '000) }\end{array}$ & $\begin{array}{l}\text { Benefit-Cost ratio } \\
\text { (B/C) (USD '000) }\end{array}$ \\
\hline 2016 & 0.0 & 0.0 & 0.0 & 500.0 & -500.0 \\
\hline 2017 & 0.0 & 0.0 & 0.0 & 400.0 & -400.0 \\
\hline 2018 & 0.0 & 0.0 & 0.0 & 400.0 & -400.0 \\
\hline 2019 & 15.2 & 29.4 & 44.6 & 0.0 & 44.6 \\
\hline 2020 & 89.0 & 171.3 & 260.4 & 0.0 & 260.4 \\
\hline 2021 & 274.7 & 528.3 & 803.0 & 0.0 & 803.0 \\
\hline 2022 & 396.4 & 762.3 & 1158.8 & 0.0 & 1158.8 \\
\hline 2023 & 433.9 & 834.5 & 1268.4 & 0.0 & 1268.4 \\
\hline 2024 & 447.9 & 861.3 & 1309.2 & 0.0 & 1309.2 \\
\hline 2025 & 462.3 & 889.0 & 1351.4 & 0.0 & 1351.4 \\
\hline 2026 & 477.2 & 917.7 & 1394.9 & 0.0 & 1394.9 \\
\hline 2027 & 492.5 & 947.2 & 1439.8 & 0.0 & 1439.8 \\
\hline 2028 & 508.4 & 977.7 & 1486.2 & 0.0 & 1486.2 \\
\hline 2029 & 524.8 & 1009.2 & 1534.0 & 0.0 & 1534.0 \\
\hline 2030 & 541.7 & 1041.7 & 1583.4 & 0.0 & 1583.4 \\
\hline 2031 & 559.1 & 1075.2 & 1634.4 & 0.0 & 1634.4 \\
\hline 2032 & 577.1 & 1109.9 & 1687.0 & 0.0 & 1687.0 \\
\hline 2033 & 595.7 & 1145.6 & 1741.3 & 0.0 & 1741.3 \\
\hline 2034 & 614.9 & 1182.5 & 1797.4 & 0.0 & 1797.4 \\
\hline 2035 & 634.7 & 1220.6 & 1220.6 & 0.0 & 1855.3 \\
\hline 2036 & 655.1 & 1259.9 & 1915.0 & 0.0 & 1915.0 \\
\hline 2037 & 676.2 & 1300.5 & 1976.7 & 0.0 & 1976.7 \\
\hline 2038 & 698.0 & 1342.3 & 2040.4 & 0.0 & 2040.4 \\
\hline 2039 & 720.5 & 1385.6 & 2106.1 & 0.0 & 2106.1 \\
\hline 2040 & 743.7 & 1430.2 & 2173.9 & 0.0 & 2173.9 \\
\hline Discounted total & 1507.60 & 2899.40 & 4407.10 & 1150.2 & 3256.8 \\
\hline
\end{tabular}

Note: The DREAM software was used to compute the total costs and benefits discounted over the entire period of simulation. These totals are not simple additions and averages

Source: Simulation estimates from DREAM analysis

corresponding changes in the benefits accruing to producers and consumers, NPV, and BCR.

Discount rate Varying the discount rate resulted in a varying total economic surplus derived from VCF, as seen in Table 4. The table shows that the economic surplus at a discount rate of $8 \%$ was USD 1,002,100, yielding an increase of over $200 \%$ compared to the surplus in the base scenario. This indicates that the lower the discount rate, the higher the value of economic surplus is. At the discount rate of $20 \%$, representing a pessimistic scenario, NPV was reduced by $48 \%$ from the base scenario; however, the BCR was 2.4, still higher than 1. The table also shows that for an optimistic discount rate of $8 \%$, the NPV increased by $62 \%$ from the base scenario, with a BCR times the cost of VCF innovation. IRR remained unchanged in the base, pessimistic, and optimistic scenarios. These results show that NPV is highest for a discount rate of $8 \%$. However, at a $10 \%$ rate, the NPV increased by $49 \%$ from the NPV in the base scenario with 
Table 4 Discount rate sensitivity analysis

\begin{tabular}{llllllllll}
\hline Scenario & $\begin{array}{l}\text { Discount } \\
\text { rate (\%) }\end{array}$ & $\begin{array}{l}\text { Total economic } \\
\text { surplus (USD '000) }\end{array}$ & $\begin{array}{l}\text { Total cost } \\
\text { (USD '000) }\end{array}$ & $\begin{array}{l}\text { Benefit-cost } \\
\text { (USD '000) }\end{array}$ & $\begin{array}{l}\text { Benefit- } \\
\text { cost ratio }\end{array}$ & $\begin{array}{l}\text { IRR } \\
\text { (USD '000) }\end{array}$ & $\begin{array}{l}\text { Change in NPV } \\
\text { (USD '000) }\end{array}$ & $\begin{array}{l}\% \\
\text { change }\end{array}$ \\
\hline Optimistic & 8 & $10,021.00$ & 1213.30 & 8807.70 & 8.25 & 36.80 & 8897.23 & - & - \\
& 10 & 7785.70 & 1194.20 & 6591.50 & 6.51 & 36.80 & 6699.83 & -2197.40 & -24.67 \\
Base & 15 & 4407.10 & 1150.20 & 3256.80 & 3.83 & 36.80 & 3406.68 & -483.08 & -12.43 \\
Pessimistic & 20 & 2687.9 & 1111.1 & 1576.8 & 2.41 & 36.80 & 1761.92 & -1644.76 & -48.28 \\
\hline
\end{tabular}

Source: Simulation estimates from DREAM analysis,

a BCR 6.5 times the cost of VCF investment. These results suggest that a discount of $10 \%$ or below is more desirable for maximum benefit, considering that the present economic situation in Nigeria makes a single-digit discount rate of $8 \%$ seemingly unrealistic.

Adoption rate From Table 5, the estimated changes in benefits as the rate of adoption changes from the base scenario show that, at an optimistic adoption rate of $70 \%$, the value of economic surplus is USD 6,196,000, while NPV increased by about 34\% from the base scenario, with a BCR 5 times the invested cost. At a conservative adoption rate of $5 \%$, the economic surplus is USD 436.50, indicating that economic surplus increases with the adoption rate. NPV is reduced by over $100 \%$ from the base scenario and became negative, at USD - 563.91, while BCR is below $1(0.3)$ and IRR less than the market rate of $15 \%$. Additionally, at an adoption rate of $10 \%$, the NPV is reduced by over $100 \%$ and negative, at USD -126.5 , BCR is below $1(0.75)$, and the IRR of $13.5 \%$ is slightly lower than the prevailing market rate. However, at an adoption rate of $15 \%$, although the NPV is reduced by $91 \%$ from the NPV in the base scenario, BCR is slightly above 1 (1.14) and the IRR is also slightly higher, at $18.1 \%$. These results suggest that an adoption rate below $15 \%$ is not desirable for VCF as a viable and profitable investment in Nigeria. Table 5 also shows that as the adoption rate increases towards the optimistic scenario, as do the NPV, BCR, and IRR.

Probability of success Table 6 shows that at an optimistic scenario holds a 90\% probability of success, where the value of economic surplus is USD 5,683,400 and NPV increases by $27 \%$ compared to the base scenario. For a pessimistic success probability of $30 \%$, the NPV decreases by about $81 \%$ compared to the base scenario and the economic surplus is USD 1,877,300, increasing as the probability of success increases. However, the BCR is above 1 (1.65) and the IRR higher than the prevailing market rate, at $22.8 \%$. This suggests that, even at a success probability of $30 \%$, VCF is profitable and viable.

Table 5 Adoption rate sensitivity analysis

\begin{tabular}{llllllllll}
\hline Scenario & $\begin{array}{l}\text { Adoption } \\
\text { rate (\%) }\end{array}$ & $\begin{array}{l}\text { Total economic } \\
\text { surplus (USD '000) }\end{array}$ & $\begin{array}{l}\text { Total cost } \\
\text { (USD '00) }\end{array}$ & $\begin{array}{l}\text { Benefit-cost } \\
\text { (USD '000) }\end{array}$ & $\begin{array}{l}\text { Benefit } \\
\text { cost ratio }\end{array}$ & $\begin{array}{l}\text { IRR } \\
\text { (USD '000) }\end{array}$ & $\begin{array}{l}\text { Change in } \\
\text { NPV (USD '000) }\end{array}$ & $\begin{array}{l}\text { \% } \\
\text { change }\end{array}$ \\
\hline Optimistic & 70 & 6196.0 & 1150.2 & 5045.7 & 5.38 & $43.7 \%$ & 5195.62 & - & - \\
Base & 50 & 4407.10 & 1150.20 & 3256.80 & 3.83 & $36.80 \%$ & 3406.68 & 1788.94 & -34.38 \\
& 15 & 1312.30 & 1150.20 & 162.00 & 1.14 & $18.10 \%$ & 311.88 & -2205.92 & -87.61 \\
& 10 & 873.90 & 1150.20 & -276.30 & 0.75 & $13.50 \%$ & -126.54 & -438.42 & - \\
\multirow{2}{*}{ Pessimistic } & $5 \%$ & 436.50 & 1150.20 & -713.70 & 0.37 & $6.90 \%$ & -563.91 & -690.45 & - \\
\hline
\end{tabular}

Source: Simulation estimates from DREAM analysis 
Table 6 Probability of success sensitivity analysis

\begin{tabular}{lllllllllll}
\hline Scenario & $\begin{array}{l}\text { Prob. of } \\
\text { success } \\
(\%)\end{array}$ & $\begin{array}{l}\text { Total } \\
\text { economic } \\
\text { surplus (B) } \\
\text { (USD '000) }\end{array}$ & $\begin{array}{l}\text { Total cost (C) } \\
\text { (USD '000) }\end{array}$ & $\begin{array}{l}\text { Benefit - } \\
\text { cost (B-C) } \\
\text { (USD '00) }\end{array}$ & $\begin{array}{l}\text { Benefit cost } \\
\text { ratio B/C } \\
\text { (USD '000) }\end{array}$ & $\begin{array}{l}\text { NPV } \\
\text { (USD '000) }\end{array}$ & $\begin{array}{l}\text { Change in NPV } \\
\text { (USD '000) }\end{array}$ & $\begin{array}{l}\% \\
\text { change }\end{array}$ \\
\hline Optimistic & 90 & 5683.4 & 1150.2 & 4533.1 & 4.94 & $41.9 \%$ & 4682.97 & - & - \\
Base & 70 & 4407.1 & 1150.2 & 3256.8 & 3.83 & $36.8 \%$ & 3406.68 & -1276.29 & -27.25 \\
Pessimistic & 30 & 1877.3 & 1150.2 & 727 & 1.63 & $22.8 \%$ & 876.91 & -1261.09 & -58.98 \\
\hline
\end{tabular}

Source: Simulation estimates from DREAM analysis

\section{Conclusions}

This study assessed the potential benefits derivable from VCF in meeting the financial needs of plantain producers towards increasing production in Nigeria. Findings from the study showed consistent evidence that VCF as a financing innovation is a viable and profitable option for financing plantain production in Nigeria. Investment in VCF started yielding benefits in the third year with benefits equaling the cost of investment in the ninth year and a total economic surplus of USD 2,173,900 at the end of the 25 -year simulation period. The sensitivity analysis showed the results remained robust even at a high discount rate of $20 \%$ and a low success probability of $30 \%$. From the results, there was a positive relationship between the effectiveness of VCF, measured in terms of NPV, and net benefit, expressed as producer and consumer surplus. It can therefore be concluded that there is strong evidence that the economic returns derivable from investing in VCF for plantain production outweigh the costs of investing in the innovation, and investing in its implementation will significantly boost plantain production in Nigeria. It is recommended that policy actions for establishing a value chain financing agency under a public-private partnership be taken by the government. Such an agency will focus on analyzing commodity value chains and implementing a VCF approach that will boost food production, as well as improve smallholder farmers' income and livelihood. However, efforts should be made to ensure that the interest rate be preferably maintained as a single digit.

\section{Limitation}

The limitation of this study is in the use of a crop (plantain) grown mostly in the southern part of the country. This is however due to financial constraint. Future studies with a crop such as maize that is widely grown across all the regions of the country is desirable to further assess the benefits derivable from implementing VCF in Nigeria to boost food production.

\footnotetext{
Abbreviations

ACGS: Agricultural Credit Guaranty Scheme; AfDB: African Development Bank; AVCF: Agricultural Value Chain Financing; BCR: Benefit-Cost Ratio; CBN: Central Bank of Nigeria; DFID: Department for International Development; DREAM: Dynamic Research Evaluation for Management; FAO: Food and Agriculture Organization; FOS: Federal Office of Statistics; GNP: Gross National Product; ICOR: Incremental Capital Output Ratio; IFPRI: International Food Policy and Research Institute; IRR: Internal Rate of Return; NBS: National Bureau of Statistics; NPV: Net Present Value; UN: United nations; VCF: Value Chain Financing; WOCCU: World Council of Credit Unions
}

\section{Acknowledgements}

The authors wish to acknowledge Dr. Wole Fatunbi of the Forum for Agricultural Research in Africa (FARA) for facilitating the partial funding granted for the data collection used in this study. Your support contributed immensely to the success of this study. 
Availability of data and materials

The dataset supporting the conclusions of this article is included within the article (and its additional file).

\section{Authors' contributions}

Corresponding Author - contributed to this paper in writing the abstract, introduction, the conceptual framework of the study as well as discussing the materials and methods employed in this paper. Co-author - contributed to this paper by running the simulation analysis through the DREAM software as well as the writing of the result and discussion section of this paper. All authors read and approved the final manuscript.

\section{Competing interests}

The authors declare that they have no competing interests.

\section{Publisher's Note}

Springer Nature remains neutral with regard to jurisdictional claims in published maps and institutional affiliations.

\section{Author details}

'Justice Development and Peace Movement (JDPM), Rural Development Programme, Oyo town, Nigeria. ${ }^{2}$ Department of Agricultural Economics, Obafemi Awolowo University, lle-Ife, Nigeria.

\section{Received: 28 February 2018 Accepted: 18 March 2019}

\section{Published online: 30 March 2019}

\section{References}

Akinola AA, Alene AD, Adeyemo R, Sanogo D, Olanrewaju AS (2009) Impacts of balanced nutrient management systems technologies in the northern Guinea savanna of Nigeria. Journal: Food, Agriculture and Environment (JFAE) 7(2):496-504

Akinyemi SOS, Aiyelaagbe IOO, Akyeampong E (2010) Plantain (Musa Spp.) cultivation in Nigeria: a review of its production, marketing and research in the last two decades. Proc. IC on Banana \& Plantain in Africa Eds.: T. Dubois et al. Acta Hort 879:211-218

Alston JM, Norton GW, Pardey PG (1995) Science under scarcity: principles and practice for agricultural research evaluation and priority setting. In: Cornell University press. NY Central, Ithaca

Anang TB, Sipiläinen T, Bäckman S, Kola J (2015) Factors influencing smallholder farmers' access to agricultural microcredit in northern Ghana. Afr J Agric Res Vol 10(24):2460-2469

Anderson JR (1992) Research priority setting in agriculture: problems in ex ante analysis. In: Lee DR, Kearl S, Upho N (eds) Assessing the impact of international agricultural research for sustainable development. Cornell International Institute for Food, Agriculture, and Development, Ithaca, pp 20-33

Avila AFD and Ayres CHS (1987) Brazilian experience in ex-post evaluation of agricultural research In Evenson, R.E.; Cruz, E.R.; Avila, A.F.D.; Palma, V.(eds.).Economic Evaluation of Agricultural Research: Methodologies and Brazilian Applications. New Haven, EMBRAPA. Yale University, Economic Growth Center, Chapter VII

Ayanwale AB, Akinola AA, Adeyemo VA (2011) Ex -ante evaluation of the economic impact of adoption of the IAR4D concept in the KKM PLS of the SSA CP:the case of maize in the Sudan savanna taskforce. Learning Publics Journal of Agriculture and Environmental Studies 2(1):161-179 20 January 2011

Bantilan MCS, Anupama KV, Joshi PK (2005) Assessing economic and environmental impacts of NRM technologies: an empirical application using the economic surplus approach. In: Shiferaw B, Freeman HA, Swinton SM (eds) Natural resource Management in Agriculture: methods of assessing impacts. CAB International Publishing, Wallingford, UK, pp $245-268$

Central Bank of Nigeria Statistical Bulletin (2016) Volume 27, December 2016

Department for International Development (2004) The importance of financial sector development for growth and poverty reduction, policy division working paper. DFID, London, pp 1-29pp

Ellinger PN, Barry PJ (2015) Farmers Guide to Credit. Available via www.farmdoc.llinois.edu/finance/ FarmersGuidetoCreditBody.htm. Accessed 9 Oct 2015

Ellis K, Lemma A, Rud J (2010) Financial inclusion, household investment and growth in Kenya and Tanzania. In: Project Briefing No 43, Overseas Development Institute, September 2010

Federal Office of Statistics (FOS) (1999) Annual Abstract of Statistics 323. Federal Office of Statistics, Abuja, Nigeria

Food and Agriculture Organization (2011). Available via: http://www.fao.org. Accessed Nov 2015

Harberger AC (1971) Three basic postulates for applied welfare economics. Journal of Economic Literature 9(3):785-797

Hareau GG, Mills BF, Norton GW (2006) The potential benefits of herbicide-resistant transgenic rice in Uruguay: lessons for small developing countries. Food Policy 31:162-179

Hussain MN (2000) Exorcism of the ghost: an alternative growth model for measuring the financing gap, African Development Bank Economic Research Papers No 5

International Food Policy and Research Institute (IFPRI) (2010). Innovations in rural and agriculture finance. Available via www. ifpri.org/publication/innovations-rural-and-agriculture-finance Accessed February 2015

Macharia I, Orr A, Simtowe F, Asfaw S (2012) Potential economic and poverty mpact of improved chickpea Technologies in Ethopia. Selected poster prepared for resentation at the International Association of Agricultural Economists (IAAE)triennial conference, Foz Do Iguaçu, Brazil 18-24 august, p 2012

Maredia M, Byerlee D, Anderson J (2000) Ex post evaluation of economic impacts of agricultural research Programmes: a tour of good practice. Paper presented to the workshop on "the future of impact assessment in CGIAR: needs, constraints, and options", standing panel on impact assessment (SPIA) of the technical advisory committee, Rome, pp 3-5

Masters WA, Coulibaly B, Sanogo D, Sidibe M, Williams A, Sanders J, Lowenberg-DeBoer J (1996) The economic impact of agricultural research: A practical guide. Department of Agricultural Economics, Purdue University, West LaFayette

Miller C, Jones L (2010) Agricultural value chain finance. Tools and lessons. FAO and Practical Action Publishing 
Mills B (1998) Ex-Ante research evaluation of and regional trade flows. J Agric Econ 49(3):391-406

Moyo S, Norton GW, Alwang J, Rhinehart I, Deom CM (2007) Peanut research and poverty reduction: impacts of variety improvement to control Peanut viruses in Uganda. Am J Agric Econ 89(2):448-460

Nkenda R, Akyeampong E (2003) Socio economic data on the plantain commodity chain in west and Central Africa. InfoMusa 12(1):8-13

Okike I (2002) Impacts and potential benefits of ITC's trypanosomiasis research and Herd management interventions in the Gambia: A consultant's report. ITC (International Trade Centre), Banjul, Gambia \& ILRI (International Livestock Research Institute), Nairobi

Okonjo-Iweala N, Madan J (2016) Shine a Light on the Gaps. In: Center for Global Development, January. 2016

Rudi N (2008) An exante economic impact analysis of developing low cost technologies for pyramiding useful genes from wild relatives into elite progenitors of cassava. MSc thesis. Faculty of the Virginia Polytechnic Institute and State University

Rusike J, Jumbo S, Ntawuruhunga P, Kawonga JM, James B, Okechukwu R, Manyong VM (2010) Ex-Ante Evaluation Of Cassava Research for Development In Malawi: A Farm Household And Random Utility Modelling Approach. In: Contributed Paper presented at the Joint 3rd African Association of Agricultural Economists (AAAE) and 48th Agricultural Economists Association of South Africa (AEASA) Conference, Cape Town, South Africa, p 2010

United Nations, Department of Economic and Social Affairs, Population Division (2015) World population prospects: the 2015 revision, key findings and advance tables. Working paper no. ESA/P/WP::241

Wander AE, Magalhaes MC, Vedovoto GL, Martins EC (2004) Using the economic surplus method to assess economic impacts of new technologies: case studies of EMBRAPA.Conference on international Agricultural Research for Development. Deutscher Tropentag 2004 Berlin. October 2004:5-7

Wood S, You L, Baitx W (2001) Dynamic research evaluation for management (DREAM), version 3 [software]. International Food Policy Research Institute (IFPRI), Washington, DC

World Council for Credit Union (WOCCU) (2009) Integrated financing for value chains-credit unions fills the agricultural lending gap and create market linkages. Technical guide, p 2009

\section{Submit your manuscript to a SpringerOpen ${ }^{\circ}$ journal and benefit from:}

- Convenient online submission

- Rigorous peer review

- Open access: articles freely available online

- High visibility within the field

- Retaining the copyright to your article

Submit your next manuscript at $\boldsymbol{\nabla}$ springeropen.com 